\title{
KRZYSZTOF ŁUSZCZEK*
}

Szczecin, Poland

ORCID ID: https://orcid.org/oooo-0003-1862-5028

\section{PEDEUTOLOGICAL ASPECTS OF USING NEW TECHNOLOGIES IN EDUCATION}

\begin{abstract}
New technologies that have been used in education are treated as the "golden mean" to remove most of the educational problems. Over time, it turns out that many of the original hopes have been disappointed. This paper tries to answer the question: Why is this happening? The historical-critical method allows analysing certain elements of the education system that are important to it and which turned out to be crucial when introducing additional technologies. That is the case with the position of a teacher in the education process. It turns out that the teacher's ideas about education can have a significant impact on his / her attitude to new technologies and thus their effectiveness. Hence, not only the preparation of teachers to use new technologies, but also shaping their ideas and building educational traditions is equally important in the effective application of new technologies in education.
\end{abstract}

Keywords: teacher; information technologies; pedeutology; culture of education.

\section{Introduction}

The use of new technologies in education has picked up the pace since the beginning of the 21st century. But attempts were made earlier to support the teaching-learning process in various ways. The technology was used to produce teaching aids. Since the beginning of the 19th century, the blackboard has become an essential piece of classroom equipment. Over time, the process of technology integration with the teaching-learning process has been progressing (Dillon, 2000). The technological

* PhD Krzysztof Łuszczek, University of Szczecin, Institute of Pedagogy, Poland; e-mail: Krzysztof. Luszczek@usz.edu.pl. 
revolution caused by the development of personal computers and the Internet has set new challenges for didactics. It has also been a challenge for existing education systems. Reforms and attempts to rebuild them have had different effects. In many countries, subsequent changes of governments brought with them proposals (as it was always emphasised - finally successful) for new changes in the education system. In the United States, each subsequent administration has introduced reforms in this area (Bill Clinton - 20oo: Educate America; George W. Bush - No Child Left Behind; Barack Obama - Race to the Top; Donald Trump - Strengthening Career and Technical Education for the 21st Century).

The new technologies in education have become increasingly important in such programmes. Their effectiveness has often been questionable, and, in many cases they were considered a total failure. In the search for those who had been responsible for this situation, attention was drawn to teachers as a potential barrier to the effective use of technology (Kirschner \& Wopereis, 2003). Undoubtedly, the teacher plays a key role in the development of the entire teaching-learning process. But does the effective use of technology in education depend only on his / her competences in this field and on the appropriate equipment of school classrooms? Past experience and research conducted over the last three decades have shown that other teacher-realted factors and the perception of his / her professional role by himself / herself may also be involved.

\section{The problem of using new technologies by teachers - a literature review}

For a long time, the basic problem of using new technologies in education was to find ways to quickly fill school classrooms with them. It was believed that the lack of proper equipment was the basic barrier to the involvement of new technologies in the teaching-learning process. Over time, the importance and role of the teacher in the whole process was noticed. At first, it was thought that he/she should be equipped with appropriate competences so that the use of new technologies would increase the effectiveness of education. However, the broad introduction of technology into schools and increasing the level of competences did not bring the expected results in many cases. At the turn of the 1980s and 1990s, a number of studies appeared, pointing to teachers as a barrier to the effective use of technology.

Jerry J. Wellington (1990) pointed out that the human factor was ignored in the preparation of teachers. Robert McCormik (1992) mentioned similar reasons. The introduction of IT (Information Technology) into schools could have been influenced not only by the level of training, but also by the personality of teachers and the level of motivation. Camillo Gobbo and Marta Girardi (2001) point out that the problem resulted from unjustified optimism, which was associated with new technologies. A number of other studies have confirmed that the teacher can be a critical point of the entire process of knowledge transfer using new technologies. John Beynon (1993) saw the problem more broadly as an element of the conflict 
between humanities and technology. The specific role of the teacher in the entire process should be explained on the basis of in-depth pedagogical theories (Ferster, 2014). Jerome Bruner in The Culture of Education (1996) broadly explained that teachers' beliefs about development of the entire teaching-learning process are placed between the theory of teaching and the school practice. A number of studies have confirmed the need to pay attention to teachers' understanding of their own role in the teaching-learning process (Woolfolk-Hoy, 2000; Clocke \& Sharif, 2001; Ruggerio \& Mong, 2015; Selwyn, 2017).

\section{A critical and historical perspective}

In many cases, the failed hopes for technological revolution in education are discussed. Perhaps the reason for this was an exaggerated optimism, a kind of "technological romanticism" and the belief that new technologies will work as some kind of deus ex machina and lead to improvement of the general situation in education (Gobbo \& Girardi, 2001). Only by applying a critical perspective can we understand the social impact of technology. The stronger the pessimistic attitude we have towards it, the more accurate assessment of problems can be, eliminating the wishful thinking (Holloway, 2002; Selwyn, 2014).

The relationship between introducing new technologies to education and the teacher is a separate problem, which researchers deal with less frequently, focusing on students. Many teachers have been enthusiastic about new technologies, although always reflected in the efficiency of their use. There is still a group of teachers accused of not using them or introducing them very slowly. Some, in connection with the introduction of new technologies, claim that the role of the teacher will be significantly reduced, while others, on the contrary, that his / her activities supported by technology will gain in effectiveness (Selwyn, 2017). The very method of preparing teachers for the use of new technologies is also criticised (Kirschner \& Wopereis, 2003).

The critical perspective becomes more focused when it is deepened with historical perspective. Looking back at the way technology is used, it is possible to capture certain regularities and see directions that are hardly visible in the shorter term. The historical approach allows for a step-by-step analysis (e.g. introduction of an educational film, educational television or digital technology in education), which can be divided into even shorter periods. It is possible to assess how one technology affects the other and what new technologies borrow from the old ones (Selwyn, 2017).

Man has been suddenly confronted with technology, while social changes occur in the long term. Often, we learn about all aspects of change at a time when technology is losing its popularity. In the first phase, we usually deal with enthusiasm for new technical solutions. That is why it is difficult to assess social effects. Only 
when enthusiasm passes, from the perspective of time and in the spirit of sound criticism, one can try to make a social assessment of changes (Selwyn, 2017).

\section{Teachers in the process of adapting new technologies to the education system}

With the dissemination of new technologies in school classrooms at the turn of the 1980 s and 1990s, research on how to use them was also undertaken. One of the problems (though not treated as the main one) was the involvement of teachers. The introduction of technology has changed the way teachers work and their approach to the teaching-learning process. The National Curriculum, being introduced in the 1980 s in Great Britain along with its ammendements, caused the teachers to shift from individual to collaborative work (Loveless, 2003). But already in the case of introducing interactive boards in British schools, it was felt that they could be used better. Teachers limited themselves to using them for PowerPoint presentations. Derek Glover and David Miller (2001) made a certain classification of the attitudes assumed by teachers when introducing new technologies to education as a byproduct of their research on interactive boards. They have identified:

- teachers as missionaries of new technologies. You can see in them enthusiasm for IT, but also skills;

- teachers preparing to use IT, but without self-confidence;

- teachers who do not use IT and remain "the old school" when creating the teaching-learning process.

In the early 1990s, Peter F. Oliva saw the Internet at school primarily as a source of knowledge with access to global resources and a platform for interactive communication. This could be used by teachers as a tool for creating joint educational projects and for making them public (Oliva, 1992).

Teachers who were eager to use IT were usually characterised by a high level of innovation. They aimed, for example, at redesigning the classroom space.. The autonomous work was promoted, but also various forms of collaboration (Jakobsdóttir, 2001).

However, the placement of new technologies in a classroom (e.g. a computer) has not been just a neutral technical act. It is also an ideological message that changes the environment of the teaching-learning process and influences the teacher's relationship with the student (Godsman \& Mangan, 1993). Research from the turn of the 1980 os and 1990s revealed that teachers, like students, succumb to the charm of new technologies. Instead of putting them in the teaching-learning process, they began to focus on devices as such and on their capabilities (Beynon, 1993).

Therefore, according to McCormick (1992), a teacher can be a barrier to introducing IT through his / her personality, level of motivation or lack of proper training. Very often IT trainings do not refer to the teaching-learning process and the specific nature of a school classroom, especially in the social aspect. The ideal teacher was seen as an activist, mentor, promoter of cooperation with students. 
IT was to effectively compensate for any lack of professionalism, especially in some areas (e.g. language learning) and give an appropriate platform for creating cooperation (Tweddle, 1993).

The appropriate training and raising the level of motivation was considered as the basic tool for overcoming the teacher's barrier to introducing new technologies. In the United Kingdom until the early 1980s, the development of standards in this area was basically left to higher education institutions. Later, various types of government agencies became gradually more involved in the whole process. The entire process found an ally in the professional culture of teachers. The conviction about the need for professional development is deeply inscribed in it. Also, it was not without significance that it was easier to find a place in the labor market (Singer \& Austin, 2003). Research carried out by the Centre for Education Research and Innovation (CERI) has shown that teachers willingly participate in this type of training, but this does not change their attitude to IT (1989). This brought one important indication that the problem of teacher involvement in the use of new technologies is not related to the level of motivation.

The American education system has also offered a wide range of training and continues to encourage continuous improvement of IT competences. After the training, the teachers try to apply the acquired qualifications to their own specialisation and school context. But still, teachers' competence in this field leaves much to be desired. On the other hand, the teachers' conviction that a simple exposure to technology will not solve the educational problems of the 21st century is strengthened (Ruggiero \& Mong, 2015).

Since the level of training and motivation has a relative effect on teachers' involvement in the use of new technologies, it may be other factors that were not taken into account or the existence of which deemed unimportant. According to Bruner, complex theories and proposed strategies often do not translate into teacher's work, they are often filtered by subjective experience and intuition in professional work. He described it as "folk pedagogy" and distinguished four patterns of teachers' ideas about students and development of the teaching-learning process. Teachers see children as followers who learn through repetition and exercise. Knowledge grows like development of a certain habit. The second group of teachers sees children as learning through didactic activities. They are willing to use different kinds of tests, checking the amount of collected data. Through the prism of the didactic process, they look at the student from the position of a third party and not from the position of the child's mind. The third group of teachers - according to Bruner (1996) - sees the student as a thinker. He / she is a student, but he / she is also a discoverer. Teachers promote discussion and cooperation with students, try to help them understand the world. In the end, the last group of teachers sees students as knowledgeable individuals. They try to help them to grasp the difference between personal knowledge and knowledge recognised in a given culture as objective. All four Bruner's concepts in the so-called "folk pedagogy" can 
apply to the use of IT at school, from treating IT as a substitute teacher to treating technology as an exploration tool (Clocke \& Sharif, 2001).

Bruner (1996) points out that there may be more such teachers' ideas about the student and the development of the teaching-learning process. He does not recognise them as infantile. Rather, they should be taken into consideration so that the introduction of innovation to education becomes more effective. Sooner or later, these two realities will be confronted anyway. In this way, for example, an innovative theory assuming that the best learning outcomes occur when we help students to independently come to generalisations is confronted with the conviction of many teachers that they are authorities who provide ready generalisations.

In the context of the use of IT, Dorit Maor and Peter Ch. Taylor (1995) speak about different cognitive orientations of teachers. The transmission orientation expresses a mechanistic approach. Knowledge is static, ready and teachers transfer it. The teaching-learning process is passive and quantitative in nature. Students are passive, they perceive themselves as "knowledge containers". In this approach, the use of IT allows for faster and more effective filling of these "containers". Whereas the individual constructivism orientation shifts the focus in the teaching-learning process towards the students. It allows them to make autonomous decisions. The teacher encourages students to be creative and build their own programmes. IT significantly extends the possibilities of autonomous operations, but its effective use in this orientation already assumes certain skills in the use of technology. In the social version of constructivism, one can see the construction of knowledge as negotiation of meanings. Knowledge arises in a certain context. IT can be its important element that stimulates the development of knowledge.

The personal orientation of teachers regarding education shows that it is not possible to assume in advance that technology improves the quality of education. Introducing new solutions has rarely been a fully predictable and controlled process (Reiser, 2001). However, technology is able to make education a more flexible process. This is particularly due to the individualisation of the entire process based on personal interests (Selwyn, 2017).

A teacher who has developed an opinion on self-efficacy is quite immune to changes in his / her own ways of teaching (Woolfolk-Hoy, 200o). He / she strives to achieve both personal and professional success. Uncertainty about technology can be seen as a threat to this goal. Hence pretended acceptance for technology with simultaneous internal conviction about its slight or even harmful influence on the teacher's work (Moore-Hayes, 2011).

\section{Education as a subjective process}

Can the teacher be perceived as a barrier to introducing new technologies to education? It seems that such a perception simplifies the problem too much and does not make it any closer to the solution. Teachers' attitudes and their perception of the student, school and the entire learning process can speak more 
than just revealed fears and lack of acceptance. One can see here a wider plane of dispute between humanities and technology. The pressure on education towards its marketisation, the elimination of everything that cannot be immediately sold on the labor market, the widespread dissemination of tests may raise questions about traditional educational values (such as the development of a master-student relationship). Isn't education in the middle of a "silent crisis", the effects of which will be felt with all the strength in the next generation (Nussbaum, 2016)? Isn't the student treated as a product of the educational process (Readings, 1996)?

Therefore, it is prudent that teachers regain an intellectual advantage in a school laden with technology. The teacher should have a superior postion over the device as well as over those who create software. This is because the teacher is an expert in developing the teaching-learning process and in matters related to knowledge and culture. Technology probably will not displace the teacher from the teachinglearning process. However, a deeper problem arises. How do we understand the entire process: as science or as art? Creativity and ability to use intuition are important for teaching. The introduction of technology to the educational process on a large scale often leads to reconfiguration of the structures and priorities of educational institutions. This in turn leads to tensions between the system and the teacher (Selwyn, 2017). Recognising this tension allows for embedding the entire process in a live context and for understanding where the difference between theory and practice comes from. In preparing teachers for using IT, one cannot ignore the "human factor". Otherwise, many of them will start to see technology as a threat. This applies not only to the fear of it replacing teachers, but also affects the sense of incompetence and even burnout syndrome.

Teachers usually learn the theory about IT, while the inclusion of technology in the education process is most often possible only after personal experience. Therefore, it is especially important for novice teachers that their way of thinking about technology shows its possibilities of building lasting access to distributed knowledge. This can stimulate the exchange of experiences and contribute to the construction of an individual path of professional advancement, raising competences and, consequently, a sense of confidence in the social role being played by them. IT can thus become a catalyst for the professional development of a teacher (Loveless, 2003).

The structure of such a knowledge platform for teachers can be diverse and include different levels. The first is the level of publication. The second level is the space of reflection. These can be descriptions of teachers' projects and reports on their implementation. The third level is the space of discussion. Experts can be invited to it. In the end, the last level is the construction space. It contains tools, tips and advice for the implementation of new projects (Kirschner \& Wopereis, 2003).

Teachers' attitude towards technology encourages to draw critical conclusions. It seems that treating a man as a weak point in the whole system as opposed to technology that is considered a "miraculous educational weapon" is wrong 
(Lovink, 2011). A certain distance, both historical and emotional, allows for getting rid of the "technological romanticism" which has its source in the eighteenthcentury optimism for the development of technology and gives the opportunity to reliably evaluate the effects of using IT in education. The role of teachers can be extremely inspiring here if they are not prejudiced to demonstrate the attitude of technological enthusiasm. Especially since IT does not support all learners in the same way. It increases learning outcomes for those who have been already active at the level of education. One can not forget that technology can offer a lot, but only to those who want and like to learn. Therefore, even if equal access to technology for everyone is ensured, the learning outcomes can be very different. In overcoming such volitional and intellectual impotence, the role of the teacher, not the machine, becomes crucial.

\section{Conclusions}

Technology creates completely new opportunities for the educational process and allows for teaching activities that were unthinkable half a century ago. Situation related to the teaching during the COVID-19 pandemic suddenly made us realise how important technology can be today regardless of the level of education. The teaching during pandemic has become a global experiment using technology at various levels of education. Technology has shown that it is a universal and didactically attractive tool. However, the use of technology in education is conditioned multidimensionally. There are several critical points in shaping this process and one of them is the teacher. Undoubtedly, the level of his / her competence in this area is important. But equally important is his / her involvement in the whole process as well as personal beliefs about shaping the teaching-learning process. Students' attitude is also important. Their educational aspirations and enthusiasm are an ideal (desirable, but not universal) response to the opportunities being provided. However, it is the teacher's responsibility to animate the whole process. However, if we expect educators to feel confident in this role, several conditions should be met:

- he / she should be equipped with appropriate competencies, and if necessary, with software and even hardware;

- he / she should be convinced of the importance of technology in education. The use of IT in education can be influenced by the teacher's personal experience and past practice. Skilful persuasion will prevent the opportunities acquired from being lost;

- $\quad$ and finally, adequate support should be provided. A separate problem is who should organise it - school, education admininistration or IT administration?

Undoubtedly, one cannot forget that the education process is deeply humanistic. It is also a meeting of people who enter into dialogue with one another. This cannot be replaced by any technology. Therefore, such traditional education values as the 
importance of the master-student relationship, should be complementary to the opportunities offered by new technologies for the development of education.

\section{References}

Beynon, J. (1993). Technological Literacy: Where Do We Go from Here. Journal of Information Technology for Teacher Education, 1(2), 7-35.

Bruner, J. (1996). The Culture of Education. London: Harvard University Press.

Centre for Education Research and Innovation (CERI). (1989). Information Technologies in Education: The Quest for Quality Software. Paris: OECD.

Clocke, S., \& Sharif, S. (2001). Why Use Information and Communications Technology? Some Theoretical and Practical Issues. Journal of Information Technology for Teacher Education, 1(2), 7-18.

Dillon, P. (2000). Innovation, Renovation and Terminological Precision. Journal of Information Technology for Teacher Education, 1(2), 3-8.

Glover, D., \& Miller, D. (2001). Running with Technology: The Pedagogic Impact of the Large-Scale Introduction of Interactive Whiteboards on one Secondary School. Journal of Information technology for Teacher Education, 3(1), 257-276.

Gobbo, C., \& Girardi, M. (2001). Teacher's Beliefs and Integration of Information and Communications Technology in Italian Schools. Journal of Information Technology for Teacher Education, 10(2), 63-85.

Godson, J., \& Mangan, J.M. (1993). Computers in Schools as Symbolic and Ideological Action. Curriculum Journal, 3, 261-276.

Holloway, J. (2002). Change the World Without Taking Power. London: Pluto Press.

Jakobsdóttir, S. (2001). Some Effects of Information and Communications Technology on Teaching and Learning in Iceland. Journal of Informational Technology for Teacher Education, 1(2), 87-100.

Kirschner, P., \& Wopereis, I. (2003). Mindtools Teacher Communities: a European Perspective. Technology, Pedagogy and Education, 1, 106-124.

Loveless, A. (2003). Information and Communication Technology as a Catalyst for Professional Growth. Technology, Pedagogy and Education, 3, 325-328.

Lovink, G. (2011). Networks Without a Cause: A Critique of Social Media. Cambridge: Polity Press.

Maor, D., \& Taylor, P.Ch. (1995). Teacher Epistemology and Scientific Inquiry in Computerized Classroom Environments. Journal of Research in Science Teaching, $32,839-854$.

McCormick, R. (1992). Curriculum Development and New Information Technology. Journal of Information Technology for Teacher Education, 1, 23-50.

Moore-Hayes, C. (2011). Technology Integration Preparedness and its Influence on Teacher - Efficacy. Canadian Journal of Learning and Technology, 3, 1-15.

Oliva, P.F. (1992). Developing the Curriculum. New York: Harper Collins. 
Reiser, R. (2001). A History of Instructional Design and Technology. Educational Technology Research and Development, 1, 53-64.

Ruggiero, D., \& Mong, Ch.J. (2015). The Teacher Technology Integration Experience: Practice and Reflection in the Classroom. Journal of Information Technology Education: Research, 14, 161-178.

Selinger, M., \& Austin, R. (2003). A Comparison of the Influence of Government Policy on Information and Communications in Technology for Teacher Training in England and Northern Ireland. Technology, Pedagogy and Education, 4, 19-38. Selwyn, N. (2014). Distrusting Educational Technology. Critical Questions for Changing Times. New York: Routledge.

Selwyn, N. (2017). Education and Technology. Key Issues and Debates. London, Oxford, New York, New Delhi: Bloomsbury.

Selwyn, N. (2017). Is technology Good for Education? Cambridge: Polity Press.

Tweddle, S. (1993). The Future Curriculum and Information Technology. Journal of Information Technology for Teacher Education, 1, 105-110.

Wellington, J.J. (1990). The Impact of IT on the School Curriculum: Downwards, Sideways, Backwards and Forwards. Journal of Curriculum Studies, 22, 57-76. Woolfolk Hoy, A.E. (2000). Changes in Teacher Self-Efficacy during Early Years of Teaching. Paper Presented at the Annual Meeting of the American Educational Research Association (28 April 20oo): http://www.learningforwardpa.org/uploads/2/o/8/5/20859956/changes_in_teacher_efficacy.pdf (accessed 17.03.2019).

\section{PEDEUTOLOGICZNE ASPEKTY WYKORZYSTANIA NOWYCH TECHNOLOGII W EDUKACJI}

Streszczenie: Nowe technologie, które trafiają do edukacji są traktowane jako „złoty środek" mający usunąć większość edukacyjnych bolączek. Po czasie okazuje się, że wiele z pierwotnych nadziei zostało zawiedzionych. Niniejszy artykuł próbuje odpowiedzieć na pytanie: Dlaczego tak się dzieje? Metoda historyczno-krytyczna pozwala przeanalizować pewne elementy systemu edukacji, które są dla niego istotne a które przy wprowadzaniu kolejnych technologii okazywały się kluczowe. Tak jest z pozycją nauczyciela w procesie edukacji. Okazuje się, że wyobrażenia nauczyciela na temat edukacji mogą mieć istotny wpływ na jego stosunek do nowych technologii a co za tym idzie na ich skuteczność. Stąd nie tylko przygotowanie nauczycieli do posługiwania się nowymi technologiami, ale także kształtowanie ich wyobrażeń i budowa tradycji edukacyjnych jest równie istotne w efektywnym zastosowaniu nowych technologii w edukacji.

Słowa kluczowe: nauczyciel; technologie informacyjne; pedeutologia; kultura edukacji. 